\title{
Romania at the beginning of World War I. A Historical and Theoretical Sketch of Foreign Policy
}

\author{
Hadrian Gorun, Associate Professor, PhD \\ "Constantin Brancusi” University of Targu -Jiu, Romania
}

URL:http://dx.doi.org/10.19044/esj.2020.v16n14p16

\begin{abstract}
This paper represents a short historical and theoretical analysis of the Romanian foreign policy at the beginning of the First World Conflagration. The study proposes an approach on this topic mainly from the perspective of realism, as a theory of international relations. The Romanian foreign policy during the Great War aimed to achieve the national interest, namely to receive the territories from the Dual Monarchy of Austria-Hungary inhabited by a Romanian population. The article valorizes the thesis of the rational actor. The Romanian state acted as a rational actor in international relations, declaring its neutrality in July 1914. The Romanian government behaved as a rational actor, being aware of the poor supplies for the army and its low level of training. Ion I.C Bratianu also attempted to get certain guarantees on obtaining the territories under Austro-Hungarian rule. So he decided to delay the moment of intervention in the war as long as possible. The analysis tries to demonstrate that the neutrality was only a temporary one due to the geographical position of the country and the evolution of the war. There was also benevolent neutrality towards the Entente and Russia. The paper shows the reasons for which Romania played the role of the balancer in the Balkan area, at least until Bulgarian intervention in the conflict. Moreover, the article demonstrates that the president of the Romanian Council of ministers, Ion I. C. Bratianu enjoyed a real monopoly on foreign policy decisions. He adopted a bandwagoning behaviour, deciding to enter World War I, alongside Entente, at the moment he considered optimal.
\end{abstract}

Keywords: World War I, Ion I. C. Bratianu, the balance of power, national interest, foreign policy, neutrality, bandwagoning, realism

\section{Introduction}

\section{A few methodological issues}

The paper tries to make a short historical and theoretical analysis of the Romanian foreign policy at the beginning of World War I, mainly in the 
first phase of Romania's neutrality. The article starts with the thesis of the rationality of the state actors in international relations. This is one of the fundamental postulates of the realist theory.

The study attempts to underline how the Romanian state performed as a rational actor in the international arena striving to achieve the national ideal. In the circumstances of the world conflict, the national ideal identified itself with the Romanian Kingdom's national interest. The national interest referred to obtaining the Romanian territories, which were parts of Austria-Hungary. At the beginning of the world war, the decision for neutrality responded in fact to Romania's national interest, because the Romanian state and particularly its army were not prepared for the military involvement. Or, in realism, the national interest is a key concept. The national interest is conceived in terms of power. The analysis also tries to underline some of the reasons for which Romania delayed as long as possible the moment of its intervention in the war.

Thus, the Romanian state made all its best to consolidate its power, its capabilities. Otherwise, an intervention in the conflict would have been a genuine military adventure. The Romanian army was poorly equipped and trained. The armaments, ammunition and war materials of good quality were insufficient. The realist thinker Hans Morgenthau mentioned the military training (namely the quantity and the quality of the officer corps and those of the armaments) among the main elements of the national power. (Morgenthau, 2007: 188-151) Lacking in enough power (mainly military power), the Romanian state was not able to fulfil the national and territorial aspirations, in fact, its national interest. The article also shows why the Romanian neutrality could not be perpetual, taking into consideration the evolution of the regional context. It also underlines the nature of the neutrality, the options and the dilemmas of the Romanian government. It demonstrates that Romania assumed the role of the balancer in the Balkan area. On the other hand, following a rule that international relations theoreticians use to highlight, the Romanian Kingdom resorted to a bandwagoning behaviour in the relations with the great powers of the Entente.

On the contrary, Romania tended to balance Bulgaria's power because the neighbour from the South of the Danube enjoyed rather similar capabilities. In these circumstances, the paper emphasizes Ion I. C. Bratianu's primordial role as the principal decision-maker in Romanian foreign policy. The paper also valorizes a few previous pieces of research and studies (Gorun, 2018: 51-41; Gorun, 2018: 225-211).

\section{Premises}

After the outbreak of the world war, the government of Bucharest had to choose between three solutions. The supreme goal was the support of the Romanian national interest. (Gorun, 2018: 212-211) These three options were: 
the intervention on the side of the Central Powers to honour the treaty of the alliance signed in 1883; neutrality, to attentively and responsibly observe the events or the alliance with the Entente. Most of the dignitaries who attended the Crown Council of Sinaia( 21st July / 3rd August 1914) decided on neutrality because they considered that unilateral and aggressive action of Austria-Hungary against Serbia absolved Romania of any commitment assumed in the treaty of 1883. (Torrey, 1999: 10) That treaty had a quasi-secret character. Until the moment of the Crown Council of Sinaia, the existence of the treaty was unknown to the public opinion and the majority of the Romanian political class. King Carol I was among the very few who knew its contents. According to Rudolf Dinu, before the outbreak of the world war, diplomacy was a domain reserved for the king. The monarch was perceived, in the context of parliamentary life, as the sole guarantee for the continuity of the foreign policy. The Crown Council's decision put an end to this state of affairs, as it was not following the will of the sovereign (Dinu, 2010: 9).

\section{The nature of the Romanian neutrality}

Regarding the treaty of 1883, the principle casus foederis could not apply because on July, 28th, 1914, the Dual Monarchy was the aggressor, not the victim of Serbia's aggression. As a consequence, the treaty signed by Romania, renewed for the last time in 1913, became obsolete. Bucharest did not assume any assignment of intervention to support the Dual Monarchy. Taking into consideration Russia's presence among the powers of the Entente, the only reasonable solution remained neutrality, at least in the beginning (Gorun, 2014: 69).

The Romanian neutrality was also called military expectation with the defence of the frontiers (Arhiva Nationala Istorica Centrala, Fund Microfilms, France, roll 101, p. I: 267; Gorun, 2020: 47). But the notion of neutrality is preferable, as it is well known in international relations. The concept of military neutrality (See Iordache, 1998) is also appropriate as due to the intense preparations made by the Romanian Kingdom all this time. The term of neutrality could be more relevant because it refers to the political and legal status of a state refusing to intervene in a conflict and join alliances and military blocks. A neutral state can maintain diplomatic relations with all the other actors of the international system, including the belligerent ones. It is important to underline that, due to tactical reasons, Romania continued to maintain relations with the Entente, as well as with the Central Powers during its neutrality. (Gorun, 2018: 42) The Romanian diplomacy negotiated the terms of the military involvement with both alliances. The Romanian government strove to keep secret all the discussions concerning the accession to the Entente in order not to generate the suspicions of the rival military 
alliance and to avoid an attack of the Central Powers. Therefore, later the Romanian state will sign a trade agreement with Germany (Ibidem: 43).

However, there was benevolent neutrality towards the Entente. After Turkey's entered the war alongside the Central Powers, Romania decided to ban the transportation of war materials meant for Turkey on its territory. But Romania had to facilitate the military transportations for Serbia. (Kiritescu, 1940: 12) This decision represented an act of courage because it could be interpreted as defiance towards Germany. In fact, Romania's declaration of neutrality caused discontentment in Berlin. Benevolent neutrality towards a belligerent block most likely represented a prelude of the accession to the respective alliance sooner or later. As to Romania, the next events clearly confirmed this tendency. (Gorun, 2018: 213) Romania's attitude was determined by the promises made by the Entente regarding the fulfilment of the national aspirations. Implicitly, the Entente supported Romanian national objectives.

But Romanian neutrality during World War I could only be temporary. At the crossroads of the great powers' opposite interests, Romania will be gradually surrounded only by belligerent states. Taking into consideration its position on Europe's geopolitical map, Romania could not afford to adopt measures regarding permanent neutrality like Switzerland (Gorun, 2020: 47).

\section{The birth of the balance of power and realpolitik in the international modern system}

\section{The failure of the idealism}

Switzerland's neutrality status had been unanimously recognized in 1648 when the Peace of Westphalia was signed and the modern international system was born. (Blin, 2006: 6-5) According to Arnaud Blin, after the conclusion of the peace treaty, the idea of a Christian united Europe was substituted by a new mechanism in international relations. This one was founded on the balance of powers and the lack of morality of the realpolitik. This realpolitik is closely related to the promotion of the national interest at all costs. The realist theory of international relations will valorize both concepts, balance of power and realpolitik. In fact, the realism paid too little attention to the ethical aspects (unlike the interwar idealism) when talking about the foreign policy objectives of a state actor. Arnaud Blin also wrote about a "Westphalian regime", that was born in 1648 . It will regulate the international politics for a few centuries to come. (Ibidem) In fact, in his opinion, there were just three ways to manage the power relations, namely the imperial hegemony, the balance of power and the collective security. The supreme accomplishment of the imperial hegemony was the Roman pattern whose multiplication was tried more times. The balance of power represented the tool chosen by the architects of the Westphalian treaty and particularly by 
its successors. The collective security that also originates in the agreements of Westphalia is the newest of the three modalities. The collective security is defined in accordance with the balance of power and tends to systematize and institutionalize the international relations so that the particular policies of the states could be coordinated with the general principles. The assumption was that the collective commitments of the countries had been founded on a security regime that was protecting the states that had assumed the respective commitments. This system was supported by the action of the international organizations which were created precisely for this goal (Ibidem: 8-7).

The idealist liberalism specific to the inter-war period stressed the role of the international organizations, proposing a collective security system. If realism considered the balance of power as the most important method to avoid the war and to preserve the peace, the idealism alleged the contrary. According to the idealism, the balance of power was not able to prevent the war. Moreover, it would represent a cause for its outbreak. The League of Nations, an international organization founded in 1919 tended to create and maintain a climate favourable to cooperation and to solve all the disputes between the international actors peacefully. It aimed at surpassing the national interests that endangered peace. (Goldstein, Pevehouse, 2008: 149, Guzzini, 2000: 51-49, Steans, Pettiford, Diez, 2005: 32) The idealist thinkers expressed the hope that the states were capable to function as a community rather than autonomous entities, whose sole concern, like in realism, was to achieve their objectives. As the evolution of the interwar events demonstrated, the liberal idealism failed to represent "a proper intellectual guide" (Jackson, Sørensen, 2010: 35) The League of Nations, an idealist project par excellence, was not able to maintain peace and to efficiently manage the international crisis.

\section{The Romanian state- balancer in the Balkan area}

During Romanian neutrality (1914-1916), the Balkan region was characterized by a special dynamic. Always loyal to a typical realistic way of acting, the Romanian Kingdom played the role of a balancer in the functioning of the Balkan balance of power during the first years of World War I. Bucharest assumed a similar mission in the second Balkan conflict. Romania intervened with the clear intention of preserving the balance of power. Defying Vienna, which had assumed the position of Sofia's protector, Romania opposed the possibility of Bulgaria gaining too much power and consequently affecting the territorial status-quo.

A victory obtained by Bulgaria over its former allies of 1912, namely Serbia and Greece, would have compromised the Balkan balance of power. The neighbour south of the Danube would have become a regional hegemonic power, an undesirable situation for the Romanian men of state (Gorun, 2018: 213, Gorun, 2014: 70). 
This paper shares Rudolf Dinu's point of view, who affirmed that after the year 1900, due to geographical, strategic and ethnic reasons, the Romanian foreign policy was fundamentally focused on the Balkan zone. The existence of a numerous Romanian population in the peninsula (the MacedoRomanians) gave Bucharest "the ethnic pretext of a status-quo in the Balkans which will determine a confrontation with the Bulgarian nationalism". (Dinu, 2010: 11-10). The peace treaty signed in the Romanian capital on the 10th of August 1913 sanctioned Romania's status as the main and the most important regional power. The Romanian state could enjoy freedom in the international arena and the right to make essential foreign policy decisions (such as the declaration of neutrality and later the entry in the war) when it considered it most favourable. Romania will continue to assume the role of balancer, deliberately maintaining itself in expectation and intervening only when it will consider there was the right moment.

As the Russian historian GrigoriiȘkundin noticed, there are different opinions in historiography regarding the moment of the reorientation in the Romanian foreign policy. Undoubtedly this process was accelerated due to Vienna's negative reaction towards the treaty of 1913, which it wanted revised in its favour. (Shkundin, 2012: 278) The representatives of the internal interventionist public opinion considered that the Russian victory in Lemberg (September 1914) and Italy's entry in war (May 1915) were favourable occasions for the Romanian intervention easily failed by the Ion I. C. Bratianu government. But the role of the public opinion is not of utmost importance in the foreign policy of a state, as the major decisions are made by the governments. The Russian diplomacy insisted on Romania's entry in the war during difficult moments to relieve the military pressure exerted by the Central Powers' troops. Naturally, on the contrary, the internal pro-interventionist activity gained ground when the military situation was more favourable to the Allies. The governmental authorities also preferred the intervention to happen in a moment of military superiority of the Entente (Gorun, 2018: 214-213).

\section{Ion I. C. Bratianu's primordial role and the bandwagoning behaviour}

This is just one reason for the adjournments of the government headed by Ion I. C. Bratianu. The further developments would prove that president of the Romanian Council of ministers was right, thus confirming his diplomatic tact. After King Carol's passing, it was Ion I. C. Bratianu who became the main foreign policy decision-maker while Queen Mary was the strongest promoter of the Entente's cause (Dinu, 2010: 14; See also Bulei, 2016).

Ion I. C. Bratianu's outstanding diplomatic qualities fully revealed during the neutrality when the diplomatic representatives of both the Entente and Central Powers were striving to obtain his aid. The virtues of the Romanian statesman were also emphasized by Grigorii Shkundin: "[...]The 
key of Romania's destiny was found in the pocket of the prime minister [...] He had a lucid and rational mind and he excellently knew to play a double game, making attractive promises, but ambiguous and noncommittal [...]" (Shkundin, 2012: 277) .

Between 1914 and 1916, proving a genuine "political despotism", Bratianu watched the foreign policy of the country, not taking into account the viewpoints of the minister of Foreign Affairs, Emanoil Porumbaru. The President of the Council of Ministers used to negotiate and made major decisions not informing the formal leader of the diplomacy. (Shkundin, 2012: 281). Moreover, EmanoilPorumbaru was ironically named "the minister foreign to affairs" (Torrey, 2014: 21) instead of the minister of foreign affairs, relevant proof of his insignificant role in Romanian diplomacy. The formal leader of the diplomacy was always in Ion I. C. Bratianu's shadow concerning foreign policy decisions. In most cases, the latter preferred to talk the most important issues directly with the diplomatic representatives of the Entente in Bucharest (Shkundin, 2012: 281).

The president of the Romanian Council of ministers did not adopt decisions quickly especially if they were vital for the success of the foreign policy of his country. Glenn E. Torrey considered Ion I. C. Bratianu to be the most suitable person for the diplomatic dissimulation necessary to temper the Central Powers, while he was discussing the terms of Romania's military involvement with the Entente's representatives. Bratianu was able to very rigorously calculate all the possible consequences of his moves. He often preferred to avoid responsibility rather than make a decision with fatal repercussions (Torrey, 2014: 20).

The agreement with Italy in September 1914, renewed in February 1915 , concerning the conditions of renouncing neutrality for the two states is not surprising, the head of the government himself havingcompared Romania's struggle for unity to that of Italy. Bratianu was aware of the importance of his mission. At the end of 1912, after the new development in the relations with the great republic of the West, he declared to the French plenipotentiary minister Jean-Camille Blondel that the Austro-Hungarian dualist empire would suffer a dissolution and: "that is why we have to be prepared [...] to receive our brothers from Transylvania." (Ibidem: 21-20). In the years of the Great War, Ionel Bratianu managed to exert a growing influence on the Royal House (on King Ferdinand I and Queen Mary as well), through the agency of the Prince Barbu Stirbey, the administrator of the Crown land. The latter became the close adviser of the king, a kind of "political guardian" of the monarch between 1914 and 1918. (Ibidem: 22-21) Glenn Torrey also emphasised Ion I. C. Bratianu's accuracy of the predictions. The American historian considered that after the French victory on the river Marne (6th September - 13th September) which saved Paris, Bratianu foresaw the 
Entente's final triumph. Later, animated by this conviction, he tried to fulfil the Romanian national program through all foreign policy démarches (Torrey, 1999: 14).

In Rudolf Dinu's opinion, in the beginning, Bratianu tried to avoid participation in the conflict using the neutrality solution. Then, the Romanian man of state adopted a bandwagoning behaviour, deciding to enter the war alongside the more powerful camp, at the optimal moment (Dinu, 2010: 1514, Gorun, 2018: 215-213).

Usually, in their relations with great powers, the weaker states incline towards bandwagoning, rather than balancing. In relations with actors with similar power, these states will rather opt for balancing. (Cioculescu in Walt, 2008: 28) It is what the officials of Bucharest preferred regarding Bulgaria (a state with military capabilities quite similar to those of Romania). But in its relations with the Entente's states, the Romanian Kingdom naturally chose to adopt a bandwagoning behaviour. When a state actor or an alliance has the biggest chances of winning in a conflict, the states prefer to join the stronger camp, rather than form coalitions. In these circumstances, the states will opt for bandwagoning (Waltz, 2006: 176).

The first scholars who used the bandwagoning notion as opposed to the term of balancing in the theory of international relations were Quincy Wright and Stephen Van Evera. (Wright, cited in Waltz, 2006: 176) A representative of the defensive neorealism, Keneth Waltz made a distinction between the bandwagoning behaviour in the internal affairs and that adopted by the state actors in their foreign policy. In the second case, the states make greater efforts to maximize their power or find allies, should they find themselves at disadvantage: "In a competition for the position of leader, the balancing is the correct behaviour where the victory of a coalition over the other leaves the weaker members of the winning coalition at the discretion of the stronger ones. None does want someone else to win; no great power wants one of them to impose itself as the leader." (Waltz, 2006: 177) The last phrase is relevant: "no great power wants one of them to impose itself as the leader." Of course, the situation is quite similar during the First World Conflagration and immediately after its end. Although they were Russia's allies, Great Britain and France did not want the former to consolidate its influence and to extend the control over the Balkans and Eastern Europe. Later, on the eve of the Peace Conference, Great Britain was afraid of the French possible claims related to the hegemony over the European continent. These fears were not realistic due to the huge effort of war made by France. After the success of the Bolshevik revolution, the civil war will outbreak in Russia. It may be surprising that Germany, defeated and punished due to the tough provisions of the peace treaty, will threaten the status-quo established at 
Versailles and will eventually destroy the international order and stability (Gorun, 2018: 48-47).

Romania will decide to intervene in the war on the side of the Quadruple Alliance (a name it received after Italy's entry in conflict, during the spring of 1915), in a favourable moment to the latter, when the final victory had become more clear. From this perspective, a state joins the stronger part intending to share with it the advantages and benefits after the achievement of the final victory. (Walt, 2008: 61) Romania's and Italy's options for foreign policy and alliance in World War I are relevant for this type of bandwagoning. (Taylor, 1989: 90-88 cited in Walt, 2008: 61) Each was promised territorial awards at the expense of the Austro-Hungarian Dual Monarchy, as a reward for the participation in the war. The weak states, unlike the great powers, express a special interest in the neighbouring powers. They are concerned mainly about the events which take place in the proximity of their borders. Moreover, weak state actors can balance when they are threatened by states with quite similar capabilities. Actually, they tend to bandwagon when they feel that their security and territorial integrity are endangered by a great power. (Walt, 2008: 71) The policy of balancing Bulgaria's power, adopted by the Bucharest government is relevant.

However, if we take into consideration the main hypothesis regarding bandwagoning, approached by Stephen Walt, Romania's alliance with the Russian empire is not surprising. Thus, for the Romanian Kingdom, Russia represented the most serious external threat. According to Walt, the states are inclined to join the most menacing power. The closer a great power is, from a geographical point of view, the more inclined are the neighbouring states to form a coalition with that great power. (Ibidem: 75) Russia was situated in Romania's immediate proximity. Therefore, the alliance between Romania and Russia starting with 4/17th August 1916, as a result of the bandwagoning policy of the former does not appear very surprising in this context.

\section{Conclusion}

The Romanian Kingdom declared its neutrality on 21 July/3 August 1914 , acting as a rational actor regarding international relations. The reasons for the decisions of the Romanian governmental authorities were the precariousness of the military training and the poor equipment with war materials and ammunition. Moreover, the government of Bucharest had to obtain clear guarantees concerning the recognition of its territorial claims. The way of action of the Romanian state was typical realistic, trying to make the most important decisions in the moments it considered to be optimal.

In its foreign policy, Romania alternated between armed neutrality while defending the frontiers (in fact benevolent neutrality towards the Entente) and bandwagoning behaviour. Therefore, the government headed by 
Ion I. C. Bratianu decided to join the Entente when the chances to win the war were greater.

\section{References:}

1. Arhiva Nationala Istorica Centrala

2. Blin, A. (2006). La Paix de Westphalie ou la naissance de l'Europe moderne. Paris: Editions Complexe

3. Bulei, I. (2016). Regina Maria. Bucuresti: Meteor Publishing

4. Dinu, R. (2010). Romania's way from neutrality to War. An analysis regarding the Romanian Foreign Policy 1912-1916. In La Grande Guerre. Histoire de la mémoire collective en France et en Roumanie. Edited by Christophe Prochasson and Florin Turcanu. Bucharest: New Europe College

5. Goldstein, J., Pevehouse, J. (2008). Relatii internationale. Translated by Andreea-Ioana Cozianu, Elena Farca, Adriana Straub. Iași: Editura Polirom

6. Gorun, H. (2020). Romania-Allies Relationship During the First World War and the Treaty of Bucharest: French and Romanian Archives Perspectives. In European Scientific Journal (pp. 46-54), Vol. 16, No.5

7. Idem (2018). Realism and Decisional Dilemmas in Romania's Foreign Policy during the Neutrality. In PHILOBIBLON. Transylvanian Journal of Multidisciplinary Research in Humanities (pp. 211-226), XXIII, No. 2

8. Idem (2018). Intre neutralitate si aliniere. Aspecte privind politica externa a Romaniei la inceputul Marelui Razboi. In Polis. Revista de stiinte politice(pp. 41-51), VI, 2(20)

9. Idem (2014). Considerations on the Romanian-Russian and Romanian-Bulgarian relations at the Beginning of World War I. A few Romanian and French Documentary Evidence. In Analele Universitatii din Craiova. Seria Istorie(pp. 67-78), Vol. XIX, No. 1 (25).

10. Guzzini, S. (2000). Realism si relatii internationale. Translated by Diana Istratescu. Iasi: Institutul European

11. Iordache, A. (1998). Reorientarea politicii externe a Romaniei si neutralitatea armata. Bucuresti: Editura Paideia

12. Jackson, R., Sørensen, G. (2010). Introduction to international relations. Theories and Approaches. 4th edition. New York: Oxford University Press

13. Kiritescu, C. (1940). Preludiile diplomatice ale razboiului de intregire. Bucuresti: Imprimeria Centrala 
14. Morgenthau, H. J. (2007). Politica intre natiuni. Lupta pentru putere si lupta pentru pace. Translated by Oana Andreea Bosoi, Alina Andreea Dragolea, Mihai Vladimir Zodian. Iasi: Polirom

15. Shkundin, G. (2012). The foreign policy of Ionel I. C. Brătianu in the vision of the foreign diplomats (January-February 1914) (pp. 277298). In Romanian and European diplomacy. From cabinet diplomacy to the 21st century Challenges. Edited by Gh. Cliveti, Adrian-Bogdan Ceobanu, Adrian Vitelaru, Ionut Nistor. Iasi, Trieste: Editura Universitătii Alexandru Ioan Cuza, Casa Editrice.

16. Steans, J., Pettiford, L., Diez, T. (2005). Introducere in relațiile internationale. Perspective si teme. Translated by Mihnea Columbeanu. Bucuresti: Editura Antet.

17. Torrey, G. E. (1999). Romania in World War I: A Collection of studies. Iasi, Oxford, Portland: The Center for Romanian Studies

18. Idem, Romania in Primul Razboi Mondial (2014). Translated by Dan Criste. Bucuresti: Meteor Publishing.

19. Walt, S. M. (2008). Originile aliantelor. Translated by Mihaela Boca. Iasi: Institutul European

20. Waltz, K. N. (2006). Teoria politicii internationale. Translated by Nicoleta Mihailescu. Iasi: Polirom. 